\title{
ANALISIS PERILAKU STRUKTUR KOMPOSIT PADA GEDUNG DI ATAS TANAH KERAS, SEDANG DAN LUNAK AKIBAT BEBAN GEMPA
}

\author{
I Wayan Giatmajaya ${ }^{1}$, Ni Ketut Sri Astati Sukawati ${ }^{2}$, I Gede Oka Darmayasa \\ 'Jurusan Teknik Sipil, Fakultas Teknik, Universitas Mahasaraswati Denpasar \\ 2 Jurusan Teknik Sipil, Fakultas Teknik, Universitas Mahasaraswati Denpasar \\ ${ }^{3}$ Jurusan Teknik Sipil, Fakultas Teknik, Universitas Mahasaraswati Denpasar \\ Jalan Kamboja No. 11 A Denpasar - Bali \\ Email : giatmajaya@gmail.com
}

\begin{abstract}
Abstrak - Dalam perencanaan struktur tahan gempa pada suatu wilayah sangat dipengaruhi oleh jenis tanah pada suatu wilayah tertentu. Dalam SNI Gempa 1726-2012 terdapat berbagai jenis tanah yang dikalsifikasikan diantaranya batuan keras, batuan, tanah keras, tanah sedang, tanah lunak dan tanah khusus. Beban gempa pada setiap jenis tanah akan memiliki faktor desain seismik yang berbeda. Hal inilah yang akan menimbulakan besaran beban gempa yang berbeda yang dialami pada suatu struktur. Penggunaan jenis struktur komposit juga menjadi hal yang efesien baik dari pengerjaannya dilapangan maupun berat sendiri yang di pikul oleh struktur komposit dibandingkan dengan struktur beton bertulang jauh lebih ringan. Selain itu perilaku komposit pada suatu struktur komposit akan terjadi apabila potensi terjadinya slip antara kedua material dapat dicegah dengan menggunakan penghubung geser (Setiawan,2008). Penelitian ini dilakukan untuk mengetahui perilaku struktur komposit di atas tanah tanah keras, tanah sedang dan tanah lunak. Selanjutnya struktur komposit dimodelkan 3 dimensi menggunakan program SAP2000 yang kemudian dianalisa pada setiap jenis tanah keras, sedang dan lunak. Analisa pada struktur akibat beban gempa menggunakan metode gaya lateral ekivalen dan metode spektrum respon ragam. Hasil analisis menunjukkan struktur mengalami gaya-gaya yang berbeda dari jenis tanah keras, tanah sedang dan tanah lunak diantaranya struktur mengalami simpangan maksimum sebesar 79,57mm, 93,06mm, 113,65mm, simpangan antar tingkat sebesar $23,05 \mathrm{~mm}, 26,96 \mathrm{~mm}, 32,93 \mathrm{~mm}$, gaya geser dasar sebesar $182,58 \mathrm{kN}$, $218,26 \mathrm{kN}, 264,56 \mathrm{kN}$, serta gaya geser tingkat sebesar $63,7 \mathrm{kN}, 74,48 \mathrm{kN}, 91 \mathrm{kN}$. Dari ketiga kondisi tanah yang di dianalisa tersebut, struktur mengalami gaya-gaya yang paling besar adalah pada kondisi tanah lunak, kemudian diikuti dengan tanah sedang dan keras.
\end{abstract}

Kata Kunci : Komposit; gempa; perilaku; tanah.

Abtract - In the planning of earthquake resistant structures in an area it is strongly influenced by the type of soil in a particular area. In the SNI for Earthquake 1726-2012, there are various types of calcified soil including hard rock, rock, hard soil, medium soil, soft soil and special soil. Earthquake loads on each type of soil will have different seismic design factors. This is what will cause different earthquake load magnitudes experienced in a structure. The use of this type of composite structure is also an efficient thing both from the work in the field and the weight borne by the composite structure compared to the much lighter reinforced concrete structure. In addition, the behavior of composites in a composite structure will occur if the potential for slip between the two materials can be prevented by using a shear connector (Setiawan, 2008). This research was conducted to determine the behavior of composite structures on hard soil, medium soil and soft soil. Furthermore, the composite structure is modeled in 3 dimensions using the SAP2000 program which is then analyzed on each type of hard, medium and soft soil. Analysis of the structure due to earthquake loads using the equivalent lateral force method and the variance response spectrum method. The results of the analysis show that the structure experiences different forces from hard, medium and soft soils, including the structure experiencing a maximum deviation of $79.57 \mathrm{~mm}, 93.06 \mathrm{~mm}, 113.65 \mathrm{~mm}$, the deviation between levels is $23.05 \mathrm{~mm}, 26.96 \mathrm{~mm}$ $32.93 \mathrm{~mm}$, the basic shear forces are $182.58 \mathrm{kN}, 218.26 \mathrm{kN}, 264.56 \mathrm{kN}$, and the level shear forces are 63.7 $\mathrm{kN}, 74.48 \mathrm{kN}, 91 \mathrm{kN}$. Of the three analyzed soil conditions, the structure experiences the greatest forces in soft soil conditions, followed by medium and hard soils.

Keywords: Composite; earthquake; behavior; soil. 


\section{PENDAHULUAN}

\subsection{Latar Belakang}

Indonesia merupakan kawasan yang terletak pada daerah pertemuan tiga lempeng (triple junction plate convergence) yaitu lempeng Eurasia, lempeng Samudera Pasifik dan lempeng India-Australia yang masing-masing bergerak ke barat dan ke utara serta relatif terhadap Eurasia. Pergerakan tiga lempeng tersebut yang sebagian berpusat di dasar Samudra Hindia, dapat meyebabkan terjadinya gempa bumi berkekuatan skala besar atau kecil. Salah satu dampak yang ditimbulkan dari gempa bumi adalah kerusakan infrastruktur. Untuk mengurangi kerusakan pada infrastruktur, perlu adanya tahap perencanaan struktur gedung tahan gempa. Perencanaan ini tidak lepas dari aspek-aspek yang harus diperhatikan dalam struktur gedung diantaranya, periode (umur) bangunan, kekakuan struktur, kondisi tanah, dan massa struktur.

Dalam perencanaan gedung konstruksi umur rencana dan massa struktur dipengaruhi oleh jenis material yang digunakan dan dimensi struktur yang direncanakan, sedangkan kondisi tanah sangat tergantung dari jenis tanah pada suatu wilayah tertentu. Jenis tanah yang berbeda tentunya memiliki kemampuan dan daya dukung tanah yang berbeda untuk menahan gaya-gaya vertikal dan horizontal yang terjadi pada suatu struktur. Serta melalui medium tanah yang bebeda akan berbeda pula energi gempa yang dihantarkan dari pusat gempa ke pondasi bangunan dan akan diteruskan ke struktur atas. Sehingga dalam suatu perencanan struktur, data tanah pada suatu wilayah tertentu harus diteliti terlebih dahulu.

Pada umumnya penggunaan struktur baja sangat banyak ditemukan dalam sebuah gedung konstruksi. Akan tetapi, penggunaan material baja sebagai struktur bangunan di Indonesia masih tergolong rendah dibandingkan dengan negara-negara lainnya, khususnya di daerah Bali sendiri. Dimana pada perencanaan gedung dengan struktur baja umumnya masih menggunakan struktur baja konvensional, karena jika menggunakan struktur baja yang biasa penampang baja yang diperlukan akan lebih besar dan kurang efisien. Selain itu, penggunaan baja sebagai struktur bangunan akan lebih baik lagi bila dikombinasikan dengan beton. Perpaduan antara baja profil dengan beton yang digabung bersama untuk memikul beban disebut struktur komposit. Penggunaan komposit yang dimaksud dalam penelitian ini adalah kombinasi beton dengan baja untuk kolom, balok baja dengan beton untuk plat. Keistimewaan yang nyata dari sistem komposit diantaranya, (1) Penghematan berat baja, (2) Penampang balok baja yang digunakan lebih kecil, (3) Kekakuan lantai meningkat, (4) Kapasitas menahan beban lebih besar dan (5) Panjang bentang untuk batang tertentu dapat lebih besar (Setiawan, 2008).

Berdasarkan penjabaran diatas, maka tugas akhir ini dilakukan analisis perilaku struktur komposit pada gedung di atas tanah yang berbeda. Adapun pembagian kelas situs tanah menurut SNI 1726 : 2012, pasal 5.3 yang didasarkan atas kolerasi penyelidikan tanah lapangan dan laboratorium diantaranya, kelas situs SA (batuan keras), SB (batuan), SC (tanah sangat padat dan batuan lunak), SD (tanah sedang), SE ( tanah lunak), SF (tanah khusus, dimana diperlukan penyelidikan geoteknik dan analisis respon spesifik). Dari kelas situs tanah diatas yang digunakan sebagai perbandingan adalah kelas situs SC, SD dan SE. Adapun perilaku struktur terhadap kondisi tanah yang ditinjau antara lain, simpangan maksimum, simpangan antar tingkat, gaya geser tingkat, serta gaya geser dasar.

\subsection{Rumusan Masalah}

Berdasarkan latar belakang diatas, maka dapat diuraikan rumusan masalah sebagai berikut ;

1. Bagaimana perilaku struktur komposit pada gedung di atas kondisi tanah yang berbeda setelah menerima beban gempa?

2. Pada jenis tanah apa struktur komposit mengalami simpangan maksimum, simpangan antar tingkat, gaya geser tingkat dan gaya geser dasar yang paling besar?

\subsection{Tujuan Penelitian}

Adapun tujuan dari penelitian ini adalah :

1. Untuk mendapatkan hasil berupa nilai 
simpangan maksimum, simpangan antar tingkat, gaya geser tingkat dan gaya geser dasar yang terjadi pada struktur komposit terhadap tiga jenis tanah yang berbeda akibat beban gempa.

2. Untuk mengatahui pada jenis tanah apa struktur komposit paling kecil mengalami penyimpanganpenyimpangan.

\subsection{Manfaat Penelitian}

Adapun manfaat dari penelitian yang dilakukan adalah :

1. Dapat dijadikan sebagai bahan acuan dalam perencanaan struktur komposit pada gedung di daerah yang berpotensi mengalami gempa yang cukup tinggi.

2. Dapat digunakan sebagai bahan referensi untuk penelitian yang akan datang khusunya untuk mahasiswa Teknik Sipil.

3. Dapat mengetahui bagaimana perilaku struktur komposit pada gedung terhadap kondisi tanah yang berbeda.

\subsection{Batasan Penelitian}

Batasan yang digunakan dalam penelitian ini adalah :

1. Gedung diperuntukan sebagai gedung perkantoran dengan ketinggian bangunan yang ditinjau hanya bertingkat 4 atau tidak boleh lebih dari 15 meter yang didasarkan pada Perda No. 16 Tahun 2009 tentang Rencana Tata Ruang Wilayah Bali.

2. Bangunan dibuat beraturan dengan 6 (enam) bentang arah sumbu $X$ dan 2 (dua) bentang arah sumbun $\mathrm{Y}$, dengan jarak masing-masing $4 \mathrm{~m}$ dan $5 \mathrm{~m}$.

3. Tidak menghitung pondasi, karena struktur dianggap sudah terjepit pada level sloof (permmukaan tanah).

4. Desain struktur berdasarkan SNI 2847 : 2013, SNI $1726: 2012$, SNI $1727: 2013$ dan SNI 1729 : 2015

5. Bangunan di bangun di wilayah dengan kategori gempa tinggi yaitu di Bali Zona I yang meliputi seluruh Kabupaten Karangasem dan Klungkung.

6. Kelas situs tanah yang ditinjau adalah tanah keras, tanah sedang dan tanah lunak.
7. Analisa struktur dibantu dengan program SAP2000 versi 15.

\section{TINJAUAN PUSTAKA}

\subsection{Pengertian Tanah}

Berdasarkan SNI 1726 : 2012, Pasal 5.1, jenisjenis tanah diklasifikasikan sebagai kelas situs SA, SB, SC, SD, SE atau SF yang diteliti dari lapisan 30 meter paling atas permukaan tanah. Dimana penetapan tersebut dilakukan melalui penyelidikan tanah di lapangan dan laboratorium, yang dilakukan oleh otoritas yang berwenang atau ahli desain geoteknik bersertifikat, dengan minimal mengukur secara independen dua dari tiga parameter tanah. Dalam hal ini, kelas situs dengan kondisi yang lebih buruk harus diberlakukan. Apabila tidak tersedia data tanah yang spesifik pada situs sampai kedalaman 30 meter, maka sifat-sifat tanah harus diestimasi oleh seorang ahli geoteknik yang memiliki sertifikat/ijin keahlian yang menyiapkan laporan penyelidikan tanah berdasarkan kondisi geotekniknya. Selain itu untuk penetapan situs SA dan SB tidak diperkenankan jika terdapat lebih dari 3 meter lapisan tanah antara dasar telapak atau rakit pondasi dan permukaan batuan dasar. Serta untuk sifat-sifat tanah tidak teridentifikasi secara jelas sehingga tidak bisa ditentukan kelas situs-nya, maka kelas situs SE dapat digunakan kecuali jika pemerintah/dinas yang berwenang memiliki data geoteknik yang dapat menentukan kelas situs SF.

\subsection{Perencanaan Bangunan Tahan Gempa}

Perencanaan struktur tahan gempa didasarkan pada metodologi capacity design. Pada cara ini struktur telah direncanakan sedemikian rupa sehingga bila struktur mengalami kondisi inelastis, maka hanya terjadi pada tempat yang ditentukan, yang memang telah direncanakan. Dimana kondisi inelastis yang terjadi tersebut juga terkontrol sebagai tempat dissipasi energi. Sedangkan bagian struktur lainnya tetap berperilaku elastis. Selain itu, dalam perencanan bangunan tahan gempa tentu banyak hal yang harus diperhatikan. Diantaranya material yang diguanakan dan pembebanan pada suatu struktur yang direncanakan agar dapat meminimalisir kemungkinan terjadinya kegagalan pada suatu konstruksi. Selain material yang kuat 
digunakan tentunya harus memiliki berat jenis yang relatif ringan, hal ini dikarenakan dapat mengurangi pembebanan yang terjadi pada suatu struktur.

Dalam pembebanan akibat berat sendiri, beban mati tambahan dan beban hidup, beban angin dan beban gempa sedang maka diharapkan struktur dapat berperilaku elastis yaitu beban hilang maka deformasi hilang. Akan tetapi pada suatu perencaan bangunan pada suatu wilayah tertentu yang memiliki kreteria gempa yang besar, struktur yang didesain secara elastis tentunya akan sangat tidak praktis dan mahal dikarenakan pengerjaan yang lama.

\subsubsection{Sistem Struktur Baja}

Struktur baja merupakan struktur dengan material yang secara alami mempunyai rasio kuat dibanding berat-volume yang tinggi, sehingga dalam penggunan material ini pada suatu gedung memiliki berat struktur yang relatif ringan. Tentunya dalam hal ini masa struktur menjadi salah satu faktor penting pada suatu bangunan tahan gempa. Dan baja merupakan seluruh macam besi yang dengan tidak dikerjakan terlebih dahulu lagi, melainkan sudah dapat ditempa. Baja adalah bahan yang serba kesamaannya yaitu homogenitasnya tinggi, terdiri dari Fe dalam bentuk Kristal dan C. Pembuatannya dilakukan sebagai pembersihan dalam temperatur yang tinggi dari besi mentah yang didapat dari proses dapur tinggi. (Setiawan, 2008)

\subsubsection{Sistem Struktur Komposit}

Struktur komposit merupakan kombinasi dari dua elemen struktur yang materialnya bebeda yang bekerja bersama -sama membentuk satu kesatuan, dimana masing-masing dari bahan/material tersebut mempunyai kekuatan sendiri-sendiri. Pada awal tahun 1930 penggunaan penampang komposit sudah mulai digunakan pada konstruksi jempabatan, tetapi untuk peraturannya baru dikeluarkan pada tahun 1944 oleh AASHTO (American Association of State Highway and Transportation Officials) tentang spesifikasi jembatan jalan raya dengan struktur komposit. Pada sebuah jembatan dengan penampang komposit ini, gaya geser longitudinal ditransfer dari balok baja ke pelat beton bertulang dengan menggunakan penghubung geser. Hal inilah yang mengakibatkan pelat beton tersebut turut ikut serta membantu untuk memikul momen lentur yang timbul. Penampang komposit ini dapat dilihat dalam Gambar 2.1.a. Sedangkan untuk pengembangan penggunaan komponen struktur komposit untuk bangunan gedung dimulai pada awal tahun 1960, yang mengacu pada spesifikasi yang dikeluarkan oleh AISC (American Institute of Steel Construction) tahun 1952. Dalam komponen struktur komposit yang digunakan dapat berupa balok baja yang diselubungi dengan beton pada Gambar 2.1.b. (Setiawan, 2008)

\subsection{Konsep Pembebanan}

Dalam suatu struktur gedung pastinya akan menerima pengaruh-pengaruh pembebanan dari luar dan dalam. Pengaruh pembebanan dari dalam disebabkan oleh sistem struktur yang terbuat dari material bermassa, yang nantinya akan memikul berat sendiri akibat pengaruh gaya gravitasi. Dan pengaruh pembebanan dari luar tentunya disebabkan oleh gaya- gaya yang bekerja dari luar struktur seperti, beban angin dan beban gempa. Berikut merupakan gambaran pembebanan yang di terima suatu struktur yang berdiri diantaranya:

\subsubsection{Beban Gravitasi}

Beban gravitasi adalah gaya tarik ke pusat bumi pada suatu benda tertentu yang berdiri diatas permukaan bumi. Pada sebuah gedung, yang mejadi beban gravitasinya adalah berat seluruh bangunan yang ada didalamnya. Berat seluruh bangunan ini berasal dari kombinasi dari berbagai pembebanan yang ada di gedung tersebut, diantaranya :

a) Beban Hidup (Live Load)

Beban hidup adalah beban gravitasi yang bekerja pada struktur dalam waktu penggunaan suatu gedung. Karena besar dan lokasi beban yang sering berubahubah, maka penentuan beban hidup secara pasti sangat sulit ditentukan. Perencanaan pembebanan untuk beban hidup disesuaikan dengan standar pembebanan SNI $1727: 2013$

b) Beban Mati (Dead Load)

Dalam memperhitungkan beban mati pada suatu struktur harus mencangkup 
elemen-elemen yang memiliki fungsi struktural dan non struktural. Untuk menghitung besarnya beban mati pada setiap elemen dilakukan dengan meninjau berat satuan material tersebut dan dikalikan dengan volume elemen

\subsubsection{Beban Angin (Wind Load)}

Beban angin adalah beban yang bekerja pada struktur akibat tekanan-tekanan dari gerakan angin. Beban angin sangat tergantung dari suau wilayah tertentu dan ketinggian struktur. Besarnya tekanan tiup harus diambil minimum sebesar $25 \mathrm{~kg} / \mathrm{m}^{2}$,(Setiawan, 2008).

\subsubsection{Beban Gempa}

Beban gempa adalah semua beban static ekuivalen yang bekerja pada struktur akibat dari pergerakan tanah arah vertikal atau horizontal dari gempa bumi. Adapun yang harus ditentukan dalam menentukan beban gempa diantaranya :

a) Kategori risiko struktur bangunan

b) Parameter spektrum respons

c) Kategori desain seismic

d) Pemilihan sistem struktur dan parameter sistem $\left(R, C d, \Omega_{0}\right)$

e) Koefisien-koefisien situs dan paramaterparameter respons spektral percepatan gempa maksimum yang dipertimbangkan risiko- tertarget $\left(M C E_{R}\right)$

f) Menentukan parameter percepatan spektral desain

\subsubsection{Kombinasi Pembebanan}

Berdasarkan peraturan yang berlaku pada SNI 1727-2013 tentang Beban minimum untuk perancangan bangunan gedung dan struktur lain, digunakan kombinasi dasar pembebanan metode desain kekuatan sebagai berikut :
a) $1.4 \mathrm{D}$
b) $1.2 \mathrm{D}+1.6 \mathrm{~L}+0.5(\mathrm{Lr}$ atau $\mathrm{R})$
c) $1.2 \mathrm{D} \pm 1.6(\mathrm{Lr}$ atau $\mathrm{R})+(\mathrm{L}$ atau $0.5 \mathrm{~W})$
d) $1.2 \mathrm{D} \pm 1.0 \mathrm{~W}+\mathrm{L}+0.5(\mathrm{Lr}$ atau $\mathrm{R})$
e) $1.2 \mathrm{D} \pm 1.0 \mathrm{E}+\mathrm{L}$
f) $0.9 \mathrm{D} \pm 1.0 \mathrm{~W}$
g) $0.9 \mathrm{D} \pm 1.0 \mathrm{E}$

\subsection{Gaya Lateral pada Struktur Bangunan}

a) Gaya geser dasar akibat gempa

Besarnya gaya geser dasar ditentukan berdasarkan persamaan :

$\mathrm{V}=\mathrm{C}_{\mathrm{s}} . \mathrm{W}$

Keterangan :

$\mathrm{C}_{\mathrm{s}}=$ koefisien respon

gempa

$\mathrm{W}=$ berat bangunan

Untuk koefisien respon gempa ditentukan dengan persamaan :

$\mathrm{Cs}=S \mathrm{DS} /(R / I e)$

Keterangan :

SDS = parameter percepatan spektrum desain $\mathrm{R}$

$\mathrm{R}=$ faktor modifikasi respon

$\mathrm{I}_{e} \quad$ = faktor keutamaan gempa

b) Distribusi vertikal gaya gempa

Gaya lateral gempa $\left(F_{x}\right)(k N)$ yang timbul disemua tingkat harus ditentukan dari persamaan berikut :

$\mathrm{F}_{\mathrm{x}}=\mathrm{C}_{\mathrm{vx}} \cdot \mathrm{V}$

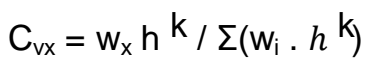

Keterangan :

$\mathrm{C}_{\mathrm{vx}}=$ faktor distribusi vertikal

$\mathrm{V}=$ gaya lateral desain total geser didasar struktur, $\mathrm{kN}$

wi \& wx = berat efektif total struktur pada tingkat yang ditinjau.

$h_{i} \& h_{x}=$ tinggi dasar struktur sampai tingkat yang ditinjau.

$\mathrm{k}=$ eksponen yang terkait periode struktur sebagai berikut:

$\mathrm{T} \leq 0,5$ detik, maka $\mathrm{k}=1 ; \mathrm{T} \geq 2,5$ detik, maka $\mathrm{k}=2$, Jika $\mathrm{T}$ antara $0,5-$ 2,5 detik, harus dilakukan dengan interpolasi.

c) Distribusi horizontal gaya gempa

Penentuan Geser tingkat desain gempa di semua tingkat $\left(\mathrm{V}_{\mathrm{x}}\right)$ dengan rumus sebagai berikut : 


$$
\begin{aligned}
& V x \underset{\mathrm{i}=\mathrm{x}}{=} \sum^{n} \\
& \text { dengan: } \\
& \mathrm{Vx}=\text { Geser tingkat desain } \\
& \text { gempa di semua tingkat. } \\
& \mathrm{Fi}=\text { Bagian dari geser dasar } \\
& \text { seismik. }
\end{aligned}
$$

d) Simpangan antar lantai

Dalam penentuan simpangan antar lantai tingkat desain $(\Delta)$, dihitung sebagai perbedaan defleksi pada pusat massa di tingkat teratas dan terbawah yang ditinjau. Pada gambar 2.8 diijinkan menghitung defleksi di dasar tingkat berdasarkan proyeksi vertikal dari pusat massa tingkat di atasnya, jika pusat massa tidak terletak segaris dalam arah vertikal. Dan desain tegangan ijin dipakai, maka $\Delta$ dihitung menggunakan gaya gempa tingkat kekuatan yang ditetapkan pada 2.6 tanpa mengalami reduksi untuk desain tegangan ijinnya. Defleksi pusat massa di tingkat $\mathrm{x}(\delta \mathrm{x})$ $(\mathrm{mm})$ harus ditentukan sesuai dengan persamaan berikut:

$$
\delta_{x}=C_{d} \cdot \delta_{x e} / I_{e}
$$

Keterangan :

$$
\begin{aligned}
C_{d}= & \text { Faktor implifikasi defleksi } \\
\delta_{x}= & \text { defleksi pada lokasi yang } \\
& \begin{array}{l}
\text { disyaratkan pada pasal ini yang } \\
\text { ditentukan dengan analisis }
\end{array} \\
& \text { elastis } \\
I_{e}= & \text { Faktor keutamaan gempa }
\end{aligned}
$$

Berikut adalah cara untuk menentukan simpangan antar tingat yaitu :

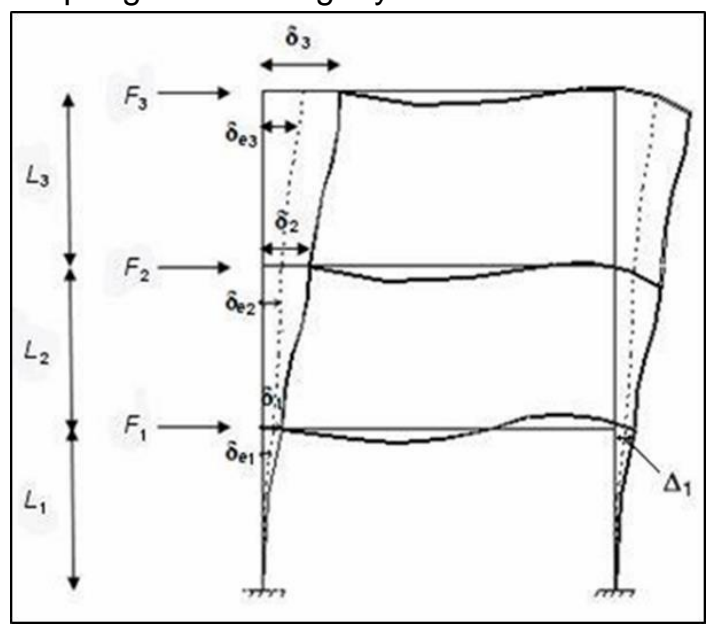

Gambar 2.1 Simpangan antar tingkat Untuk di tingkat 3
$\Delta_{3} \quad=\left(\right.$ eз $\left.-\delta_{e 2}\right) C_{d} / I_{e} \leq \Delta a$

$\delta_{e 3}=$ perpindahan elastis yang dihitung akibat gaya gempa desain tingkat kekuatan

$\delta 3=$ e3 $\mathrm{Cd} / \mathrm{le}=>$ perpindahan yang diperbesar

F3 = gaya gempa desain tingkat kekuatan

Untuk di tingkat 2

$$
\begin{aligned}
& \Delta 2=(e 2-\delta e 1) C d / l e \leq \Delta a \\
& \text { \&e2 = perpindahan elastis yang } \\
& \text { dihitung akibat gaya gempa } \\
& \text { desain tingkat kekuatan } \\
& \delta 2=\delta \mathrm{e} 2 \mathrm{Cd} / \mathrm{Ie}=>\text { perpindahan yang } \\
& \text { diperbesar } \\
& \text { F2 = gaya gempa desain tingkat } \\
& \text { kekuatan }
\end{aligned}
$$

Untuk di tingkat 1

$$
\begin{aligned}
& \Delta 1 \quad=\delta 1 \leq \Delta \mathrm{a} \\
& \delta \mathrm{e} 1=\text { perpindahan elastis yang dihitung } \\
& \delta 1=\delta e 1 \mathrm{Cd} / \mathrm{le}=>\text { perpindahan yang } \\
& \text { diperbesar } \\
& \mathrm{F} 1 \text { = gaya gempa desain tingkat } \\
& \text { kekuatan } \\
& \triangle \mathrm{i}=\text { simpangan antar lantai } \\
& \Delta \mathrm{i} / \mathrm{Li} \quad=\text { rasio simpangan antar lantai } \\
& \delta 3=\text { perpindahan total }
\end{aligned}
$$

e) Batasan simpangan antar lantai tingkat desain $(\Delta)$ Simpangan antar lantai tingkat desain disyaratkan tidak boleh melebihi simpangan antar lantai ijin $(\Delta a)$ seperti tabel dibawah ini:

Dalam penelitian ini simpangan

antar lantai ijin di gunakan

rumus :

$\Delta a=0,020 \times h_{s x}$

Keterangan :

$\Delta a=$ Simpangan lantai ijin

$h_{s x}=$ Tinggi tingkat di bawah tingkat $\mathrm{x}$ 


\section{METODOLOGI PENELITIAN}

\subsection{Deskripsi Penelitian}

Penelitian ini dilakukan untuk mengetahui perilaku struktur komposit pada gedung bagian atas di berbagai kondisi tanah, dan tidak memperhitungkan pondasi karena struktur dianggap sudah terjepit pada level sloof. Perilaku yang dimaksud adalah simpangan maksimum, simpangan antar tingkat, gaya geser tingkat, serta gaya geser dasar dari berbagai kondisi tanah yang berbeda. Metode yang digunakan dalam penelitian ini adalah metode studi analitis, yang merupakan pemecahan masalah teknis secara analitis atau dengan suatu model. Dimana struktur dimodelkan menggunakan program SAP2000 versi 15 berdasarkan peraturan perencanaan gedung yang berlaku sesuai Standar Nasinal Indonesia (SNI). Selanjutnya model struktur yang telah didesain dari SAP2000 akan dianalisis kembali pada 3 (tiga) jenis tanah yang berbeda untuk mendapatkan gaya-gaya yang diinginkan sebelumnya. Adapun data dan gambar geometri bangunan yang akan dianalisis diantaranya:

1) Tipe bangunan : diperuntukan untuk gedung perkantoran

2) Wilayah gempa : Zona I di Bali

3) Jenis tanah : Lunak, Sedang dan Keras

4) Sistem Rangka Pemikul Momen : Khusus

5) Tinggi bangunan $: 14.8 \mathrm{~m}$

6) Jumlah lantai : : 4 lantai

7) Luas bangunan :24 m x 10m

8) Struktur bangunan : Struktur Komposit

9) Mutu beton (fc') : $: 25 \mathrm{MPa}$

10) Mutu baja (fy) : : BJ $370 \mathrm{Mpa}$

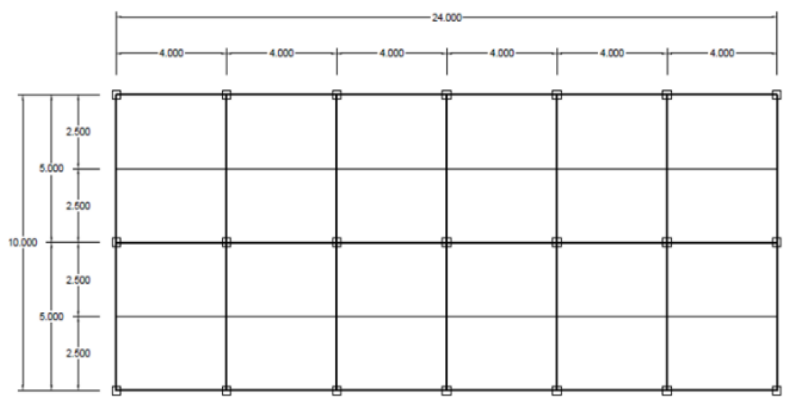

Gambar 3.1 Denah Balok dan Kolom

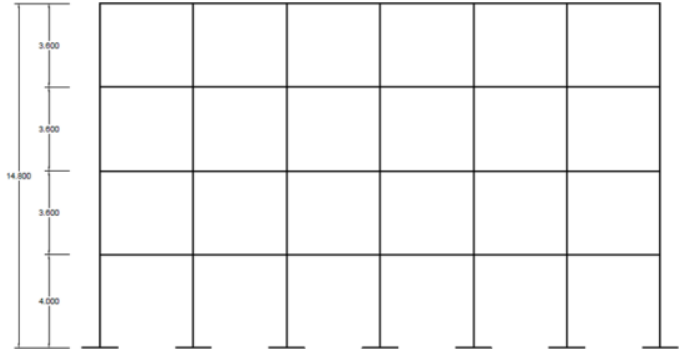

Gambar 3.2 Portal Memanjang

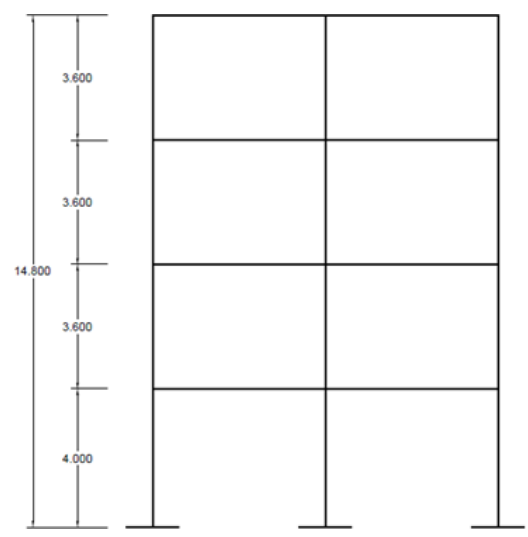

Gambar 3.3 Portal Memendek

Pembebanan yang diperhitungkan dalam penelitian ini sesuai dengan SNI 1727-2013 diantaranya :

1. Beban hidup lantai gedung untuk kantor sebesar $2,40 \mathrm{kN} / \mathrm{m}^{2}=240 \mathrm{~kg} / \mathrm{m}^{2}$

2. Beban hidup atap datar sebesar 0,96 $\mathrm{kN} / \mathrm{m} 2=96 \mathrm{~kg} / \mathrm{m} 2$

3. Berat jenis beton bertulang sebesar 2400 $\mathrm{kg} / \mathrm{m} 3$

4. Berat jenis baja sebesar $7850 \mathrm{~kg} / \mathrm{m} 3$

5. Beban plafond sebesar $18 \mathrm{~kg} / \mathrm{m} 2$

6. Beban lantai keramik sebesar $24 \mathrm{~kg} / \mathrm{m} 2$

3.2 Jenis dan Sumber Data

\subsubsection{Jenis Data}

a) Rumusan masalah 1 "Bagaimana perilaku struktur gedung komposit diatas kondisi tanah yang berbeda setelah menerima beban gempa?" untuk dapat menjawab pertanyaan tersebut menggunakan data berupa (1) data kelas situs tanah, (2) zona gempa I di daerah Bali, (3) SNI 1726:2012 tentang "Tata cara perencanaan ketahanan gempa untuk struktur bangunan gedung dan non gedung", (4) SNI 1727:2013 tentang "Beban minimum untuk perancangan bangunan gedung dan struktur lain", (5) SNI 2847:2013 tentang "Persyaratan beton struktural untuk bangunan gedung 
dan (6) SNI 1729:2015 tentang Spesifikasi untuk bangunan gedung baja struktural".

b) Rumusan masalah 2 "Pada jenis tanah apa struktur gedung komposit mengalami simpangan maksimum, simpangan antar tigkat, gaya geser tingkat dan gaya geser dasar yang paling besar?" Untuk dapat menjawab pertanyaan tersebut menggunakan data berupa hasil analisis struktur komposit di SAP2000 dengan jenis tanah yang berbeda diantara (1) hasil simpangan maksimum, (2) hasil simpangan antar tingkat, (3) hasil gaya geser tingkat serta (4) hasil gaya geser dasar.

\subsection{Teknik Analisis Data}

Teknik analisis data merupakan suatu langkah yang paling menentukan dari suatu penelitian, dikarenakan dengan adanya analisa data yang nantinya berfungsi untuk menyimpulkan hasil penelitian. Dalam menganalisis data untuk penelitian ini, peneliti sepenuhnya menggunakan program SAP2000 versi 15 yang sesuai dengan peraturan yang berlaku guna untuk memperoleh hasil yang diharapkan. Dalam hal ini data yang sudah dikumpulkan akan di input ke program SAP2000 sesuai peraturan-peraturan dalam perencanaan gedung yang ada. Adapun tahapan analisis data yang dilakukan untuk mendapatkan hasil akhir yaitu :

1. Tahap analisis : yang dimana dalam tahapan ini dilakukan permodelan struktur, pendefinisian properties materials, dimensi penampang, jenis pembebanan, dan kombinasi sampai pada menganalisis gaya-gaya dalam struktur menggunakan program SAP2000.

2. Tahap desain : yaitu dalam tahapan ini menggunakan data peraturan SNI 28472013 sebagai syarat dimensi suatu penampang yang layak kedalam program SAP2000.

3. Jika penampang yang direncanakan sesuai dengan peraturan, maka dilanjutkan dengan menguji struktur komposit pada gedung tersebut pada jenis tanah yang berbeda.

4. Dan yang terakhir adalah membanding gaya- gaya yang diperoleh dari analisis program SAP2000 dari masing-masing jenis tanah yang berbeda, untuk menentukan pada jenis tanah apa struktur gedung komposit mengalami gaya-gaya yang paling besar.

\section{HASIL DAN PEMBAHASAN}

\subsection{Data Pemodelan Struktur Komposit}

Dalam pemodelan struktur ini menggunakan data- data material seperti tabel 4.1 dibawah ini.

Tabel 4.1 Jenis material dan spesifikasinya

\begin{tabular}{|c|c|c|c|c|c|}
\hline $\begin{array}{c}\text { Jenis } \\
\text { Material }\end{array}$ & $\begin{array}{c}\text { Tegangan } \\
\text { Leleh (fv) } \\
\mathrm{MPa}\end{array}$ & $\begin{array}{c}\text { Tegangan } \\
\text { Putus (fu) } \\
\mathrm{MPa}\end{array}$ & $\begin{array}{l}\text { Berat } \\
\text { Jenis } \\
\mathrm{kg} / \mathrm{m}^{3}\end{array}$ & $\begin{array}{c}\text { Modulus } \\
\text { Elastisitas (E) } \\
\mathrm{MPa}\end{array}$ & $\begin{array}{c}\text { Rasio } \\
\text { Poisson }\end{array}$ \\
\hline BJ 37 & 240 & 370 & 7.850 & $2 \times 10^{5}$ & 0,3 \\
\hline $\begin{array}{l}\text { Tulangan } \\
\text { Longitudinal }\end{array}$ & 400 & 600 & 7.850 & $2 \times 10^{5}$ & 0,3 \\
\hline $\begin{array}{l}\text { Tulangan } \\
\text { Sengkang }\end{array}$ & 240 & 360 & 7.850 & $2 \times 10^{5}$ & 0,3 \\
\hline $\begin{array}{l}\text { Beton f's } 25 \\
\text { Mpa }\end{array}$ & & & 2.400 & $\begin{array}{c}4700 \times 25^{(0,5)} \\
=23.500\end{array}$ & 0,2 \\
\hline
\end{tabular}

\subsection{Perhitungan Beban}

\subsubsection{Beban mati}

1. Atap

Tebal pelat $\quad=10 \mathrm{~cm}=0,1 \mathrm{~m}$

Tebal spesi $\quad=2 \mathrm{~cm}$

Berat jenis beton $=2.400 \mathrm{~kg} / \mathrm{m}^{3}$

Berat jenis spesi per $\mathrm{cm}$ tebal $=21$ $\mathrm{kg} / \mathrm{m}^{2}$ Berat sendiri

pelat atap $=0,1 \times 2.400=240 \mathrm{~kg} / \mathrm{m}^{2}$

Berat spesi $=2 \times 21=42 \mathrm{~kg} / \mathrm{m}^{2}$

Berat plafon $\quad=18 \mathrm{~kg} / \mathrm{m}^{2}$

Berat MEP $\quad=\underline{15 \mathrm{~kg} / \mathrm{m}^{2} \pm}$

Jumlah beban mati

pada pelat atap $\quad=315 \mathrm{~kg}$

2. Lantai

Tebal pelat $\quad=12 \mathrm{~cm}=0,12 \mathrm{~m}$

Tebal spesi $\quad=2,5 \mathrm{~cm}$ Berat

jenis beton $=2.400 \mathrm{~kg} / \mathrm{m}^{3}$

Berat jenis spesi per $\mathrm{cm}$ tebal $=21$

$\mathrm{kg} / \mathrm{m}^{2}$

Berat sendiri pelat

lantai $=0,12 \times 2.400=288 \mathrm{~kg} / \mathrm{m}^{2}$ 


$\begin{array}{ll}\text { Berat spesi }=2,5 \times 21 & =52,5 \mathrm{~kg} / \mathrm{m}^{2} \\ \text { Berat keramik } & =24 \mathrm{~kg} / \mathrm{m}^{2} \\ \text { Berat plafon } & =18 \mathrm{~kg} / \mathrm{m}^{2} \\ \text { Berat MEP } & =15 \mathrm{~kg} / \mathrm{m}^{2} \pm \\ & \\ \text { mlah beban mati pada } & \\ \text { at lantai } & =397,5 \mathrm{~kg} / \mathrm{m}^{2} \\ & =398 \mathrm{~kg} / \mathrm{m}^{2}\end{array}$

\subsubsection{Beban Hidup}

1. Beban hidup atap datar $=0,96 \mathrm{kN} / \mathrm{m}^{2}=$ $96 \mathrm{~kg} / \mathrm{m}^{2}$

2. Beban hidup lantai untuk kantor $=2,4$ $\mathrm{kN} / \mathrm{m}^{2}=240 \mathrm{~kg} / \mathrm{m}^{2}$

\subsection{Penentuan dimensi awal}

\subsubsection{Balok}

1. Balok anak dicoba pada gedung dengan profil baja IWF $148 \times 100 \times 6 \times 9$. Untuk menentukan layak atau tidaknya suatu penampang, dapat dilihat pada langkah run analysis pada program SAP2000.

2. Balok 1 dicoba pada gedung lantai 1,2 dan 3 dengan profil baja IWF 244 $\times 175 \times 7 \times 11$. Untuk menentukan layak atau tidaknya suatu penampang, dapat dilihat pada langkah run analysis pada program SAP2000.

3. Balok 2 dicoba pada gedung lantai 4 dengan profil baja IWF $169 \times 125 \times 5,5 \times 8$. Untuk menentukan layak atau tidaknya suatu penampang, dapat dilihat pada langkah run analysis pada program SAP2000.

\subsubsection{Kolom}

1. Kolom 1 (K1) untuk lantai 1,2 dan 3

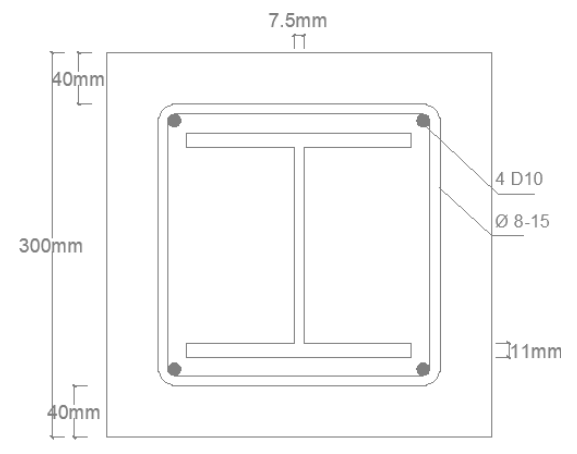

Gambar 4.1 Detail penampang kolom 1
Dibuat penampang beton ukuran $30 \mathrm{~cm} \times 30 \mathrm{~cm}$ dengan luas $A_{c}=90.000 \mathrm{~mm}^{2}$ Profil baja IWF $175 \times 175 \times 7,5 \times 11 \times 12$ dengan luas $A_{s}=$ $5.121 \mathrm{~mm}^{2}$

a. Selimut beton $=40 \mathrm{~mm} \geq 40 \mathrm{~mm}$

(ok)

b. Periksa terhadap syarat luas minimum profil baja

$$
\frac{A s}{A c}=\frac{5.121}{90.000} \times 100 \%=5,7 \% \geq 4 \%(o k)
$$

c. Periksa syarat jarak sengkang/pengikat lateral:

Jarak sengkang $=150 \mathrm{~mm} \leq 2 / 3 \times 300=$ 200 mm (ok)

d. Periksa syarat tulangan sengkang /lateral :

Luas tulangan lateral $>0,18 \times 150$

$1 / 4 \times \pi \times 8^{2}=50,24 \mathrm{~mm}^{2}>27 \mathrm{~mm}^{2}$

(ok)

e. Periksa syarat luas tulangan longitudinal: Jarak antar tulangan longitudinal

$=300-2(40)-2(8)-10=194 \mathrm{~mm}$

Luas tulangan longitudinal $>0,18 \times$ 194

$1 / 4 \times \pi \times 10^{2}=78,5 \mathrm{~mm}^{2}>34,92 \mathrm{~mm}^{2}$ (ok)

2. Kolom 2 (K2) untuk lantai 4

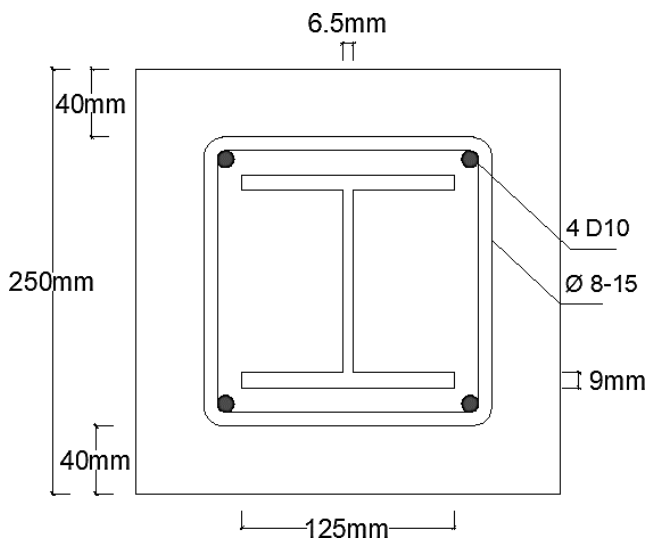

Gambar 4.2 Detail penampang kolom 2

Dibuat penampang beton ukuran $25 \mathrm{~cm} \times$ $25 \mathrm{~cm}$ dengan luas $A_{c}=62.500 \mathrm{~mm}^{2}$ profil baja IWF $125 \times 125 \times 6,5 \times 9 \times 10$ dengan luas $A_{s}=3.031 \mathrm{~mm}^{2}$

a. Selimut beton $=40 \mathrm{~mm} \geq 40 \mathrm{~mm}$ (ok)

b. Periksa terhadap syarat luas minimum profil baja 


$$
\frac{A s}{A c}=\frac{3.031}{62.500} X 100 \%=4,85 \% \geq 4 \%(o k)
$$

c. Periksa syarat jarak sengkang/pengikat lateral: Jarak sengkang $=150 \mathrm{~mm} \leq 2 / 3$ $\times 250=166,7 \mathrm{~mm}$ (ok)

d. Periksa syarat tulangan sengkang /lateral: Luas tulangan lateral $>0,18 \times$ 150

$1 / 4 \times \pi \times 8^{2}=50,24 \mathrm{~mm}^{2}>27 \mathrm{~mm}^{2}$ (ok)

e. Periksa syarat luas tulangan longitudinal: Jarak antar tulangan longitudinal $250-2(40)-2(8)-10=144 \mathrm{~mm}$ Luas tulangan longitudinal $>0,18 \times 144$ $1 / 4 \times \pi \times 10^{2}=78,5 \mathrm{~mm}^{2}>25,92 \mathrm{~mm}^{2}$ (ok)

\subsection{Pemodelan Struktur Komposit}

Dalam pemodelan struktur komposit ini dibuat dengan menggunakan program SAP2000 v.15 dan semua gaya-gaya yang terjadi akan dihitung oleh program itu sendiri. Berikut adalah tampilan modeling dengan data-data dan pembebanan yang berlaku sesuai Standar Nasional Indonesia.

\subsubsection{Model 3D}

Untuk membuat pemodelan pada program SAP2000, terlebih dahulu harus menentukan denah gedung yang akan dimodelkan. Pada tugas akhir ini gedung dimodelkan dengan bentuk 3 dimensi yaitu jumlah bentang arah $\mathrm{x}$ sebanyak 6 dengan jarak $4 \mathrm{~m}$, jumlah bentang arah y sebanyak 4 dengan jarak $5 \mathrm{~m}$ dan jumlah tingkat atau arah $z$ sebanyak 4 dengan jarak $4 \mathrm{~m}$ untuk $\mathrm{z} 1$ kemudian 3,6 m untuk $\mathrm{z} 2$, z3 dan z4. Selanjutnya Pilih Menu File - New Model - 3d Frames kemudian masukkan data-data diatas lalu ok. Maka akan muncul model dengan ukuran yang sudah dimasukkan seperti gambar 4.3 dibawah :

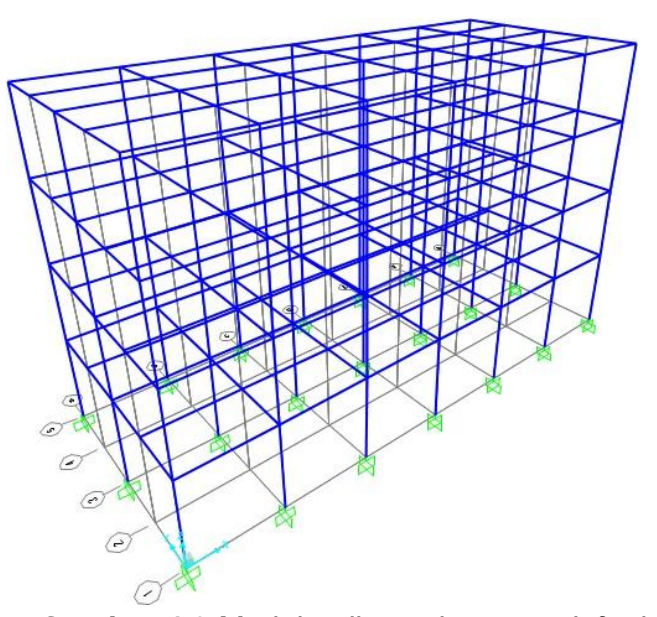

Gambar 4.3 Model 3 dimensi secara default

\subsubsection{Model struktut 3 dimensi pada program SAP2000}

Dalam hal ini pemodelan struktur komposit 3 dimensi sesuai dengan dimensi yang di tentukan di awal seperti gambar di bawah ini

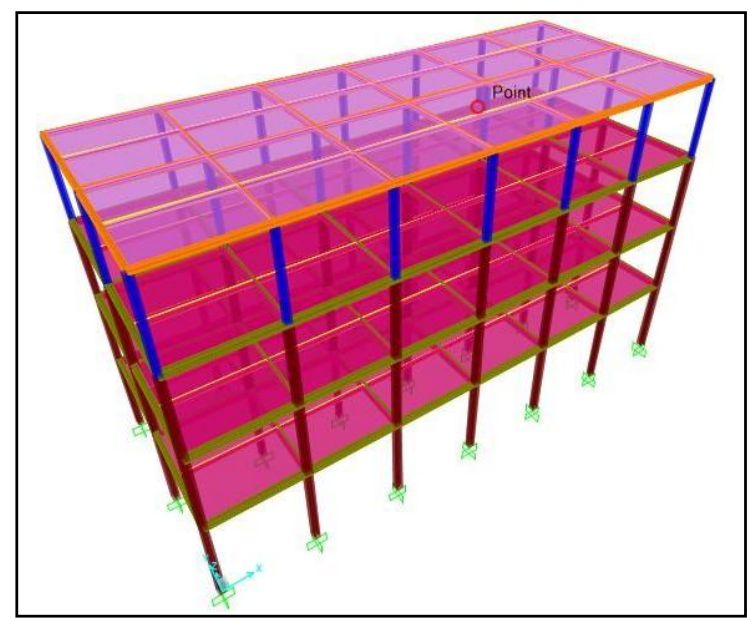

Gambar 4.4 Model struktur komposit 3 dimensi

\subsection{Menentukan Simpangan}

Untuk menentukan nilai simpangan pada struktur yang diakibatkan oleh beban gempa pada masing-masing jenis tanah yang berbeda pertama harus mencari nilai perpindahan elastis dengan cara, setelah melakukan run analysis, Pilih Menu DisplayPilih Show Deformed Shape - pilih beban gempa arah $\mathbf{x} / \mathbf{y}$ - kemudian sorot pada joint tiap lantai yang paling kanan di grid yang sama untuk arah $x-z$ maupun $y-z$, karena kolom paling kanan yang mengalami simpangan paling besar dan gunakan satuan $\mathrm{mm}$. berikut adalah hasil simpangan yang diperoleh dari program SAP2000. 
Tabel 4.2 Besar simpangan arah $x$

\begin{tabular}{|c|c|c|c|}
\hline \multirow{2}{*}{ Lantai } & \multicolumn{3}{|c|}{ Simpangan Akibat Gaya Gempa Arah X(U1) } \\
\cline { 2 - 4 } & $\begin{array}{c}\text { Tanah Keras } \\
(\mathbf{m m})\end{array}$ & $\begin{array}{c}\text { Tanah Sedang } \\
(\mathbf{m m})\end{array}$ & $\begin{array}{c}\text { Tanah Lunak } \\
(\mathbf{m m})\end{array}$ \\
\hline $\mathbf{4}$ & 14.4673 & 16.9202 & 20.6643 \\
\hline $\mathbf{3}$ & 11.3852 & 13.3155 & 16.2620 \\
\hline $\mathbf{2}$ & 8.0837 & 9.4543 & 11.5464 \\
\hline $\mathbf{l}$ & 3.8926 & 4.5526 & 5.5600 \\
\hline
\end{tabular}

Tabel 4.3 Besar simpangan arah y

\begin{tabular}{|c|c|c|c|}
\hline \multirow{2}{*}{ Lantai } & \multicolumn{3}{|c|}{ Simpangan Akibat Gaya Gempa Arah Y (U2) } \\
\cline { 2 - 4 } & $\begin{array}{c}\text { Tanah Keras } \\
(\mathbf{m m})\end{array}$ & $\begin{array}{c}\text { Tanah Sedang } \\
(\mathbf{m m})\end{array}$ & $\begin{array}{c}\text { Tanah Lunak } \\
\text { ( mm) }\end{array}$ \\
\hline $\mathbf{4}$ & 14.9655 & 17.5029 & 22.3360 \\
\hline $\mathbf{3}$ & 11.9553 & 13.9823 & 17.8433 \\
\hline $\mathbf{2}$ & 8.5477 & 9.9970 & 12.7574 \\
\hline $\mathbf{l}$ & 4.1861 & 4.8958 & 6.2477 \\
\hline
\end{tabular}

\subsubsection{Perhitungan Simpangan Maksimun}

Simpangan maksimum akibat beban gempa dari arah $\mathrm{x}$ dan y dihitung menggunakan data dari simpangan yang diperoleh dari program SAP2000 dengan menggunakan rumus sebagai berikut :

$$
\begin{array}{ll}
\delta & =\delta_{e x} \times C_{d} / I_{e} \\
K e t & : \\
\delta & =\text { Simpangan Maksimum } \\
C d & =\text { Faktor Pembesaran Defleksi } \\
l e & =\text { Faktor Keutamaan Gempa } \\
\delta e x & =\text { Simpangan tiap lantai }
\end{array}
$$

\begin{tabular}{|c|c|c|c|c|}
\hline $\begin{array}{l}\text { La } \\
\text { nta } \\
\text { i }\end{array}$ & $\begin{array}{l}\text { Simpang } \\
\text { an }(\delta e) \\
(\mathrm{mm})\end{array}$ & $\begin{array}{l}\text { Faktor } \\
\text { Pembesa } \\
\text { ran } \\
\text { Defleksi } \\
\quad(C d)\end{array}$ & $\begin{array}{l}\text { Faktor } \\
\text { Keutama } \\
\text { an } \\
\text { Gempa } \\
\text { (le) }\end{array}$ & $\begin{array}{l}\text { Simpang } \\
\text { an } \\
\text { Maksimu } \\
\mathrm{m} \delta(\mathrm{mm})\end{array}$ \\
\hline \multicolumn{5}{|c|}{ Pada Jenis Tanah Keras/C } \\
\hline 4 & 14.4673 & 5.5 & & 79.57015 \\
\hline 3 & 11.3852 & 5.5 & & 62.6186 \\
\hline 2 & 8.0837 & 5.5 & & 44.46035 \\
\hline 1 & 3.8926 & 5.5 & & 21.4093 \\
\hline \multicolumn{5}{|c|}{ Pada Jenis Tanah Sedang/D } \\
\hline 4 & 16.9202 & 5.5 & & 93.0611 \\
\hline 3 & 13.3155 & 5.5 & & 73.23525 \\
\hline 2 & 9.4543 & 5.5 & & 51.99865 \\
\hline 1 & 4.5526 & 5.5 & & 25.0393 \\
\hline \multicolumn{5}{|c|}{ Pada Jenis Tanah Lunak/E } \\
\hline 4 & 20.6643 & 5.5 & & 113.65365 \\
\hline 3 & 16.262 & 5.5 & & 89.441 \\
\hline
\end{tabular}

1. Simpangan Maksimum Arah $\mathrm{x}$

Tabel 4.4 Besar simpangan maksimum arah $\mathrm{x}$

\begin{tabular}{|r|r|r|r|r|}
\hline 2 & 11.5464 & 5.5 & 1 & 63.5052 \\
\hline 1 & 5.56 & 5.5 & 1 & 30.58 \\
\hline
\end{tabular}

Simpangan Maksimum Arah X

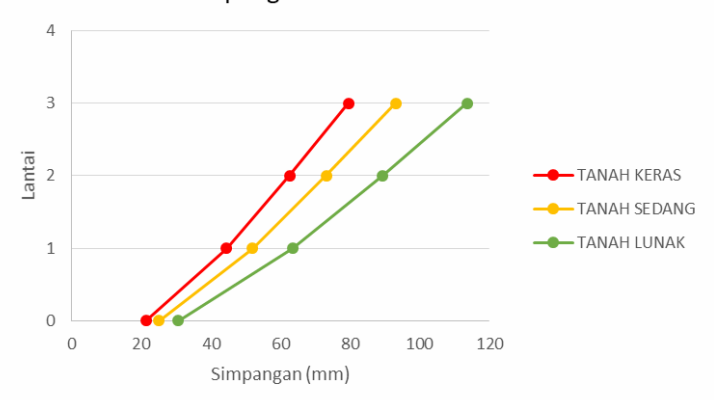

Gambar 4.5 Grafik simpangan maksimum arah x

Dari hasil perhitungan diatas bahwa simpangan maksimum arah $\mathrm{x}$ terjadi pada lantai 4 baik pada kondisi tanah keras, sedang dan lunak. Dan urutan untuk nilai simpangan maksimum paling besar terjadi pada kondisi tanah lunak dengan nilai $113,65365 \mathrm{~mm}$,

\begin{tabular}{|c|c|c|c|c|}
\hline $\begin{array}{l}\text { La } \\
\text { nta }\end{array}$ & $\begin{array}{l}\text { Simpanga } \\
\mathrm{n}(\delta \mathrm{e}) \\
(\mathrm{mm})\end{array}$ & \begin{tabular}{|l|} 
Faktor \\
Pembesa \\
ran \\
Defleksi \\
$(C d)$
\end{tabular} & $\begin{array}{l}\text { Faktor } \\
\text { Keutamaa } \\
\text { n Gempa } \\
\quad \text { (le) }\end{array}$ & $\begin{array}{l}\text { Simpang } \\
\text { an } \\
\text { Maksim } \\
\text { um } \delta \\
(\mathrm{mm})\end{array}$ \\
\hline
\end{tabular}
kemudian tanah sedang dengan nilai 93,0611 $\mathrm{mm}$ dan yang terakhir tanah keras dengan nilai $79,57015 \mathrm{~mm}$.

2. Simpangan Maksimum arah y

Tabel 4.5 Besar simpangan maksimum arah y

\begin{tabular}{r|r|r|r|r|}
\hline \multicolumn{5}{|c|}{ Pada Jenis Tanah Keras/C } \\
\hline 4 & 14.9655 & 5.5 & 1 & 82.31025 \\
\hline 3 & 11.9553 & 5.5 & 1 & 65.75415 \\
\hline 2 & 8.5477 & 5.5 & 1 & 47.01235 \\
\hline 1 & 4.1861 & 5.5 & 1 & 23.02355 \\
\hline \multicolumn{5}{|c|}{ Pada Jenis Tanah Sedang/D } \\
\hline 4 & 17.5029 & 5.5 & 1 & 96.26595 \\
\hline 3 & 13.9823 & 5.5 & 1 & 76.90265 \\
\hline 2 & 9.997 & 5.5 & 1 & 54.9835 \\
\hline 1 & 4.8958 & 5.5 & 1 & 26.9269 \\
\hline \multicolumn{5}{|r|}{ Pada Jenis Tanah Lunak/E } \\
\hline 4 & 22.336 & 5.5 & 1 & 122.848 \\
\hline 3 & 17.8433 & 5.5 & 1 & 98.13815 \\
\hline 2 & 12.7574 & 5.5 & 1 & 70.1657 \\
\hline 1 & 6.2477 & 5.5 & 1 & 34.36235 \\
\hline
\end{tabular}




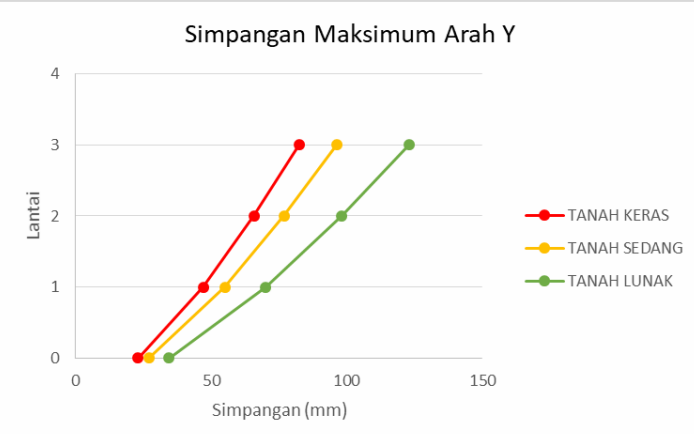

Gambar 4.6 Grafik simpangan maksimum arah y

Dari hasil perhitungan diatas bahwa simpangan maksimum arah y terjadi pada lantai 4 baik pada kondisi tanah keras, sedang dan lunak. Dan urutan untuk nilai simpangan maksimum paling besar terjadi pada kondisi tanah lunak dengan nilai $122,848 \mathrm{~mm}$, kemudian tanah sedang dengan nilai 96,26595 $\mathrm{mm}$ dan yang terakhir tanah keras dengan nilai $82,31025 \mathrm{~mm}$.

\subsection{Simpangan Antar Tingkat}

Simpangan antar tingkat dihitung tidak boleh melebihi nilai dari simpangan lantai ijin tiap lantai/ $\Delta a$ yang dihitung menggunkan rumus dibawah ini :

1. Lantai 1

$$
\begin{aligned}
\Delta \alpha & =0,020 \times h_{s x} \\
& =0,020 \times 4000 \mathrm{~mm}=80 \mathrm{~mm}
\end{aligned}
$$

2. Lantai 2, 3 dan 4

$$
\begin{aligned}
\Delta \alpha & =0,020 \times h_{s x} \\
& =0,020 \times 3600 \mathrm{~mm} \quad=75 \mathrm{~mm}
\end{aligned}
$$

Ket $: \Delta \alpha=$ Simpangan lantai ijin

$h_{s x}=$ Tinggi tingkat di bawah tingkat $\mathrm{x}$

\subsubsection{Simpangan Antar Tingkat Arah X}

Untuk menghitung nilai simpangan antar lantai maksimum akibat beban gempa pada arah $x$ dan y menggunakan rumus seperti dibawah :

$$
\Delta \quad=\left(\delta_{e 1}-\delta_{e 0}\right) \times C_{d} / l_{e}
$$

$$
\begin{array}{ll}
\text { Ket } & : \\
\Delta & =\text { Simpangan antar lantai } \\
C_{d} & =\text { Faktor Pembesaran Defleksi } \\
l_{e} & =\text { Faktor Keutamaan Gempa } \\
\delta_{e x} & =\text { Simpangan tiap lantai }
\end{array}
$$

\begin{tabular}{|c|c|c|c|c|c|c|c|}
\hline $\begin{array}{l}\text { Lan } \\
\text { tai }\end{array}$ & $\begin{array}{l}\text { Simp } \\
\text { anga } \\
n \\
(\delta \text { e }) \\
(\mathrm{mm})\end{array}$ & \begin{tabular}{|l|} 
Fakto \\
r \\
Pemb \\
esara \\
n \\
Defle \\
ksi \\
\multicolumn{1}{c}{$(C$} \\
\multicolumn{1}{c}{$d)$} \\
\end{tabular} & $\begin{array}{l}\text { Fakto } \\
\text { r } \\
\text { Keuta } \\
\text { maan } \\
\text { Gem } \\
\text { pa } \\
\text { (le })\end{array}$ & 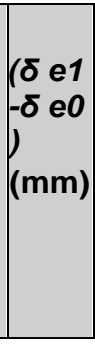 & $\begin{array}{l}\text { Simp } \\
\text { anga } \\
\mathbf{n} \\
\text { Antar } \\
\text { Lanta } \\
\mathbf{i}(\Delta) \\
(\mathrm{mm})\end{array}$ & $\begin{array}{l}\text { Simp } \\
\text { anga } \\
n \\
\text { Lanta } \\
\text { i } \\
\text { ljin } \\
(\Delta \alpha) \\
(\mathrm{mm})\end{array}$ & $\begin{array}{l}\text { Sya } \\
\text { rat } \\
(\Delta< \\
\Delta \alpha)\end{array}$ \\
\hline \multicolumn{8}{|c|}{ Pada Jenis Tanah Keras/C } \\
\hline 4 & $\begin{array}{l}14.4 \\
673\end{array}$ & 5.5 & 1 & \begin{tabular}{|r|}
3.08 \\
21 \\
\end{tabular} & $\begin{array}{l}16.95 \\
155 \\
\end{array}$ & 72 & ok \\
\hline 3 & $\begin{array}{l}11.3 \\
852\end{array}$ & 5.5 & 1 & $\begin{array}{r}3.30 \\
15\end{array}$ & $\begin{array}{l}18.15 \\
825\end{array}$ & 72 & ok \\
\hline 2 & $\begin{array}{l}8.08 \\
37\end{array}$ & 5.5 & 1 & \begin{tabular}{|r|}
4.19 \\
11 \\
\end{tabular} & $\begin{array}{l}23.05 \\
105\end{array}$ & 72 & ok \\
\hline 1 & \begin{tabular}{l|}
3.89 \\
26
\end{tabular} & 5.5 & 1 & \begin{tabular}{|r|}
3.89 \\
26
\end{tabular} & $\begin{array}{l}21.40 \\
93\end{array}$ & 80 & ok \\
\hline \multicolumn{8}{|c|}{ Pada Jenis Tanah Sedang/D } \\
\hline 4 & $\begin{array}{l}16.9 \\
202\end{array}$ & 5.5 & 1 & \begin{tabular}{|r|}
3.60 \\
47
\end{tabular} & $\begin{array}{l}19.82 \\
585\end{array}$ & 72 & ok \\
\hline 3 & $\begin{array}{l}13.3 \\
155\end{array}$ & 5.5 & 1 & \begin{tabular}{|r|}
3.86 \\
12 \\
\end{tabular} & $\begin{array}{l}21.23 \\
66 \\
\end{array}$ & 72 & ok \\
\hline 2 & $\begin{array}{l}9.45 \\
43\end{array}$ & 5.5 & 1 & \begin{tabular}{|r|}
4.90 \\
17 \\
\end{tabular} & $\begin{array}{l}26.95 \\
935 \\
\end{array}$ & 72 & ok \\
\hline 1 & $\begin{array}{l}4.55 \\
26\end{array}$ & 5.5 & 1 & \begin{tabular}{|r|}
4.55 \\
26 \\
\end{tabular} & \begin{tabular}{|l|}
25.03 \\
93 \\
\end{tabular} & 80 & ok \\
\hline \multicolumn{8}{|c|}{ Pada Jenis Tanah Lunak/E } \\
\hline 4 & $\begin{array}{l}20.6 \\
643\end{array}$ & 5.5 & 1 & \begin{tabular}{|r|}
4.40 \\
23 \\
\end{tabular} & $\begin{array}{l}24.21 \\
265\end{array}$ & 72 & ok \\
\hline 3 & $\begin{array}{l}16.2 \\
620 \\
\end{array}$ & 5.5 & 1 & \begin{tabular}{|r|}
4.71 \\
56 \\
\end{tabular} & \begin{tabular}{|l}
25.93 \\
58 \\
\end{tabular} & 72 & ok \\
\hline 2 & $\begin{array}{l}11.5 \\
464 \\
\end{array}$ & 5.5 & 1 & \begin{tabular}{|r|}
5.98 \\
64 \\
\end{tabular} & $\begin{array}{l}32.92 \\
52 \\
\end{array}$ & 72 & ok \\
\hline 1 & $\begin{array}{l}5.56 \\
00\end{array}$ & 5.5 & 1 & \begin{tabular}{|r|}
5.56 \\
00 \\
\end{tabular} & 30.58 & 80 & ok \\
\hline
\end{tabular}

Hasil perhitungan simpangan antar lantai maksimum pada arah $\mathrm{x}$ dapat dilihat pada tabel dan diagram dibawah ini

Tabel 4.6 Simpangan antar tingkat arah $\mathrm{x}$

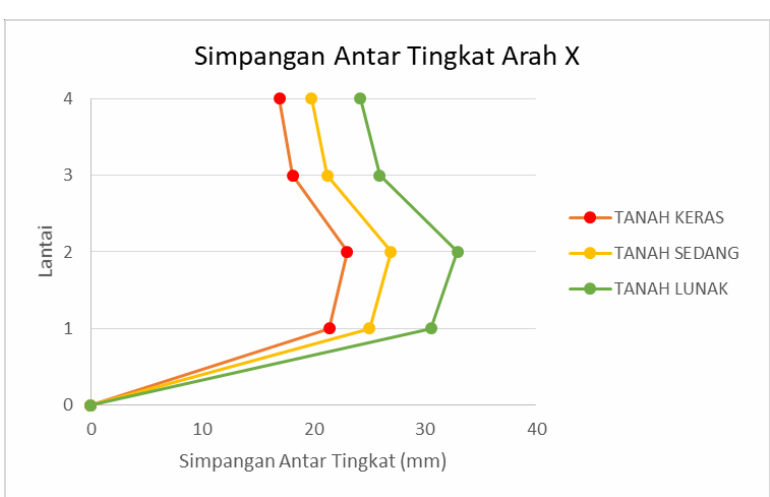

Gambar 4.7 Diagram simpangan antar tingkat $\operatorname{arah} \mathrm{x}$

Dari hasil perhitungan diatas, bahwa kondisi struktur pada tanah lunak pada saat menerima beban gempa arah $\mathrm{x}$ memiliki simpangan antar lantai maksimum yang paling besar, yang 
kemudian diikuti pada tanah sedang dan tanah keras. Dan untuk nilai simpangan antar lantai maksimum yang paling besar terjadi pada lantai 2 pada ketiga jenis tanah tersebut.

\subsubsection{Simpangan Antar Tingkat Arah $Y$}

Hasil perhitungan simpangan antar lantai maksimum pada arah y dapat dilihat pada tabel dan diagram dibawah ini

Tabel 4.7 Simpangan antar tingkat arah y

\begin{tabular}{|c|c|c|c|c|c|c|c|}
\hline $\begin{array}{l}\mathrm{L} \\
\mathrm{a} \\
\mathrm{nt} \\
\text { ai }\end{array}$ & $\begin{array}{l}\text { Simpa } \\
\text { ngan } \\
(\delta \text { e }) \\
(\mathrm{mm})\end{array}$ & $\begin{array}{l}\text { Faktor } \\
\text { Pembes } \\
\text { aran } \\
\text { Defleksi } \\
\text { (Cd } \\
\text { ) }\end{array}$ & \begin{tabular}{|l|} 
Faktor \\
Keuta \\
maan \\
Gemp \\
a \\
(l e )
\end{tabular} & $\begin{array}{l}\left(\begin{array}{lll}\delta & e & 1 \\
-\delta & e & 0 \\
) & \\
(\mathrm{mm})\end{array}\right.\end{array}$ & $\begin{array}{l}\text { Simpa } \\
\text { ngan } \\
\text { Antar } \\
\text { Lanta } \\
\text { i }(\Delta) \\
(\mathrm{mm})\end{array}$ & \begin{tabular}{|l|} 
Simpa \\
ngan \\
Lantai \\
ljin $(\Delta$ \\
a) \\
$(\mathrm{mm})$
\end{tabular} & $\begin{array}{l}\text { Sya } \\
\text { rat } \\
(\Delta< \\
\Delta \alpha)\end{array}$ \\
\hline \multicolumn{8}{|c|}{ Pada Jenis Tanah Keras/C } \\
\hline 4 & $\begin{array}{l}14.9 \\
655\end{array}$ & 5.5 & 1 & $\begin{array}{r}3.01 \\
02 \\
\end{array}$ & $\begin{array}{l}16.55 \\
61\end{array}$ & 72 & ok \\
\hline 3 & $\begin{array}{l}11.9 \\
553\end{array}$ & 5.5 & 1 & $\begin{array}{r}3.40 \\
76 \\
\end{array}$ & $\begin{array}{l}18.74 \\
18\end{array}$ & 72 & ok \\
\hline 2 & $\begin{array}{l}8.54 \\
77 \\
\end{array}$ & 5.5 & 1 & $\begin{array}{r}4.36 \\
16 \\
\end{array}$ & $\begin{array}{l}23.98 \\
88 \\
\end{array}$ & 72 & ok \\
\hline 1 & $\begin{array}{l}4.18 \\
61\end{array}$ & 5.5 & 1 & $\begin{array}{r}4.18 \\
61 \\
\end{array}$ & $\begin{array}{l}23.02 \\
355\end{array}$ & 80 & ok \\
\hline \multicolumn{8}{|c|}{ Pada Jenis Tanah Sedang/D } \\
\hline 4 & $\begin{array}{l}17.5 \\
029\end{array}$ & 5.5 & 1 & $\begin{array}{r}3.52 \\
06 \\
\end{array}$ & $\begin{array}{l}19.36 \\
33\end{array}$ & 72 & ok \\
\hline 3 & $\begin{array}{l}13.9 \\
823 \\
\end{array}$ & 5.5 & 1 & $\begin{array}{r}3.98 \\
53 \\
\end{array}$ & $\begin{array}{l}21.91 \\
915 \\
\end{array}$ & 72 & ok \\
\hline 2 & $\begin{array}{l}9.99 \\
70 \\
\end{array}$ & 5.5 & 1 & $\begin{array}{r}5.10 \\
12 \\
\end{array}$ & $\begin{array}{l}28.05 \\
66\end{array}$ & 72 & ok \\
\hline 1 & $\begin{array}{l}4.89 \\
58\end{array}$ & 5.5 & 1 & $\begin{array}{r}4.89 \\
58 \\
\end{array}$ & $\begin{array}{l}26.92 \\
69\end{array}$ & 80 & ok \\
\hline \multicolumn{8}{|c|}{ Pada Jenis Tanah Lunak/E } \\
\hline 4 & $\begin{array}{l}22.3 \\
360 \\
\end{array}$ & 5.5 & 1 & $\begin{array}{r}4.49 \\
27 \\
\end{array}$ & $\begin{array}{l}24.70 \\
985\end{array}$ & 72 & ok \\
\hline 3 & $\begin{array}{l}17.8 \\
433 \\
\end{array}$ & 5.5 & 1 & $\begin{array}{r}5.08 \\
59 \\
\end{array}$ & $\begin{array}{l}27.97 \\
245\end{array}$ & 72 & ok \\
\hline 2 & $\begin{array}{l}12.7 \\
574 \\
\end{array}$ & 5.5 & 1 & $\begin{array}{r}6.50 \\
97 \\
\end{array}$ & $\begin{array}{l}35.80 \\
335\end{array}$ & 72 & ok \\
\hline 1 & $\begin{array}{l}6.24 \\
77 \\
\end{array}$ & 5.5 & 1 & $\begin{array}{r}6.24 \\
77 \\
\end{array}$ & $\begin{array}{l}34.36 \\
235\end{array}$ & 80 & ok \\
\hline
\end{tabular}

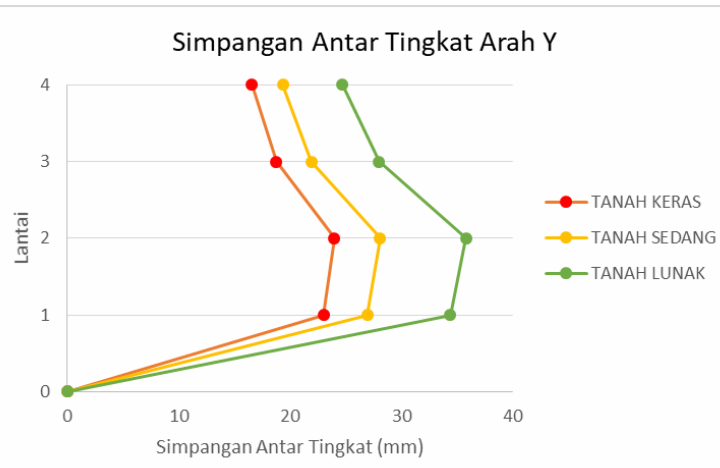

Gambar 4.8 Diagram simpangan antar tingkat arah y

Dari hasil perhitungan diatas, bahwa kondisi struktur pada tanah lunak pada saat menerima beban gempa arah y memiliki simpangan antar lantai maksimum yang paling besar, yang kemudian diikuti pada tanah sedang dan tanah keras. Dan untuk nilai simpangan antar lantai maksimum yang paling besar terjadi pada lantai 2 pada ketiga jenis tanah tersebut.

\subsection{Gaya Geser Dasar}

Gaya geser dasar pada struktur di program SAP2000 ditentukan dengan cara menjumlahkan semua gaya geser tiap kolom pada lantai 1, berikut adalah masing-masing gaya geser dasar pada struktur di kondisi tanah yang berbeda dengan arah gaya yang berbeda

1. Gaya geser dasar arah $x$

Gaya geser dasar pada arah $x$ di masingmasing jenis tanah yaitu sebesar 182,58 $\mathrm{kN}$ untuk jenis tanah keras, 218,26 kN untuk tanahsedang serta $264,56 \mathrm{kN}$ untuk jenis tanah lunak. Dari ketiga jenis tanah ini, yang memiliki gaya geser dasar paling besar adalah struktur komposit pada jenis tanah lunak. Berikut adalah tabel dan grafik gaya gesr dasar arah $\mathrm{x}$.

Tabel 4.8 Gaya geser dasar arah x

\begin{tabular}{|l|l|l|l|}
\hline \multirow{2}{*}{$\begin{array}{l}\text { Lanta } \\
\text { i }\end{array}$} & \multicolumn{3}{|c|}{ Gaya Geser Dasar (V) arah X (kN) } \\
\cline { 2 - 4 } & $\begin{array}{l}\text { Tanah } \\
\text { Keras/C }\end{array}$ & $\begin{array}{l}\text { Tanah } \\
\text { Sedang/D }\end{array}$ & $\begin{array}{l}\text { Tanah } \\
\text { Lunak/E }\end{array}$ \\
\hline 4 & 63.7 & 74.48 & 91 \\
\hline 3 & 125.84 & 147.23 & 179.79 \\
\hline 2 & 166.86 & 199.16 & 238.37 \\
\hline 1 & 182.58 & 218.26 & 264.56 \\
\hline V (kN) & $\mathbf{1 8 2 . 5 8}$ & $\mathbf{2 1 8 . 2 6}$ & $\mathbf{2 6 4 . 5 6}$ \\
\hline
\end{tabular}

Grafik Gaya Geser Dasar (V) ArahX

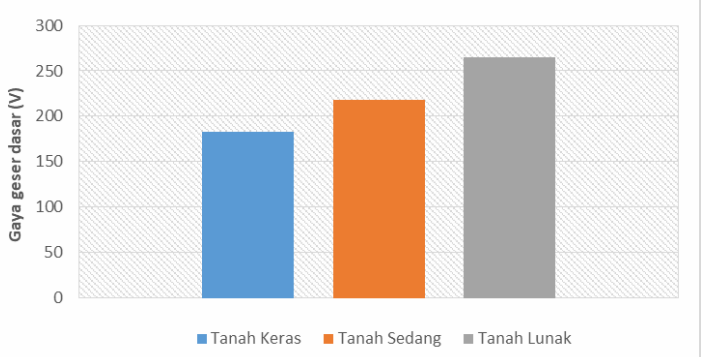

Gambar 4.9 Grafik gaya geser dasar arah x

2. Gaya geser dasar arah y

Gaya geser dasar pada arah y di masingmasing jenis tanah yaitu sebesar 178,61 $\mathrm{kN}$ untuk jenis tanh keras, 208,87 kN untuk tanah sedang serta 266,54 kN untuk jenis tanah lunak. Dari ketiga jenis tanah ini, yang memiliki gaya geser dasar 
paling besar adalah struktur komposit pada jenis tanah lunak. Berikut adalah tabel dan grafik gaya geser dasar arah y.

Tabel 4.9 Gaya geser dasar arah y

\begin{tabular}{|l|l|l|l|}
\hline \multirow{2}{*}{ Lantai } & \multicolumn{4}{|l|}{ Gaya Geser Dasar (V) arah Y (kN) } \\
\cline { 2 - 4 } & $\begin{array}{l}\text { Tanah } \\
\text { Keras/C }\end{array}$ & $\begin{array}{l}\text { Tanah } \\
\text { Sedang/D }\end{array}$ & $\begin{array}{l}\text { Tanah } \\
\text { Lunak/E }\end{array}$ \\
\hline 4 & 62.37 & 71.78 & 91.61 \\
\hline 3 & 121.07 & 141.52 & 180.59 \\
\hline 2 & 160 & 187.19 & 238.82 \\
\hline 1 & 178.61 & 208.87 & 266.54 \\
\hline V (kN) & $\mathbf{1 7 8 . 6 1}$ & $\mathbf{2 0 8 . 8 7}$ & $\mathbf{2 6 6 . 5 4}$ \\
\hline
\end{tabular}

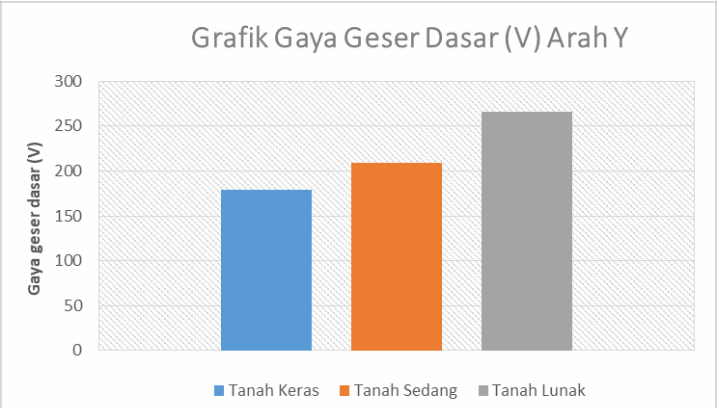

Gambar 4.10 Grafik gaya geser dasar arah y

\subsection{Gaya Geser Tingkat}

Gaya geser tingkat arah $\mathrm{x}$ dan y dihitung dari hasil selisih dari tiap gaya geser pada lantai dengan gaya lantai diatasnya. Berikut adalah tabel perhitungan gaya geser antar tingkat dari masing- masing jenis tanah yang berbeda.

1. Gaya geser tingkat arah $\mathrm{x}$

Gaya geser tingkat pada arah $x$ yang paling besar terjadi pada tingkat 4 pada masing-masing kondisi tanah yang berbeda. Sedangkan untuk struktur yang mengalami gaya geser tingkat yang paling besar terjadi pada jenis tanah lunak. Hal ini dapat dilihat dalam tabel dan diagram dibawah ini.
Tabel 4.10 Gaya geser tingkat arah x

\begin{tabular}{|c|c|c|c|c|c|c|}
\hline \multirow{2}{*}{$\begin{array}{l}\text { Lan } \\
\text { tai }\end{array}$} & \multicolumn{3}{|c|}{$\begin{array}{l}\text { Gaya Geser tiap } \\
\text { lantai Arah X }\end{array}$} & \multicolumn{3}{|c|}{$\begin{array}{l}\text { Gaya Geser } \\
\text { Tingkat (Fx) }\end{array}$} \\
\hline & $\begin{array}{l}\text { Tana } \\
\mathbf{h} \\
\text { Keras } \\
\text { /C }\end{array}$ & \begin{tabular}{l}
\multicolumn{1}{c}{ Tana } \\
$\mathbf{h}$ \\
Sedan \\
g/D
\end{tabular} & $\begin{array}{l}\text { Tana } \\
\text { h } \\
\text { Lunak } \\
\text { /E }\end{array}$ & $\begin{array}{l}\text { Tana } \\
\mathbf{h} \\
\text { Keras } \\
\text { /C } \\
\end{array}$ & $\begin{array}{l}\text { Tan } \\
\text { ah } \\
\text { Seda } \\
\text { ng/D }\end{array}$ & $\begin{array}{l}\text { Tan } \\
\text { ah } \\
\text { Luna } \\
\text { k/E }\end{array}$ \\
\hline 4 & 63.7 & \begin{tabular}{|l|}
74.4 \\
8 \\
\end{tabular} & 91 & 63.7 & \begin{tabular}{|l|}
74.4 \\
8
\end{tabular} & 91 \\
\hline 3 & $\begin{array}{l}125.8 \\
4\end{array}$ & $\begin{array}{l}147 . \\
23\end{array}$ & $\begin{array}{l}179 . \\
79\end{array}$ & $\begin{array}{l}62.1 \\
4 \\
\end{array}$ & $\begin{array}{l}72.7 \\
5\end{array}$ & $\begin{array}{l}88 . \\
79\end{array}$ \\
\hline 2 & $\begin{array}{l}166.8 \\
6\end{array}$ & $\begin{array}{l}199 . \\
16\end{array}$ & $\begin{array}{l}238 . \\
37\end{array}$ & $\begin{array}{l}41.0 \\
2 \\
\end{array}$ & $\begin{array}{l}51.9 \\
3\end{array}$ & $\begin{array}{l}58 . \\
58\end{array}$ \\
\hline 1 & $\begin{array}{l}182.5 \\
8\end{array}$ & $\begin{array}{l}218 . \\
26\end{array}$ & $\begin{array}{l}264 . \\
56\end{array}$ & $\begin{array}{l}15.7 \\
2\end{array}$ & $\begin{array}{l}19 . \\
1\end{array}$ & $\begin{array}{l}26 . \\
19\end{array}$ \\
\hline
\end{tabular}

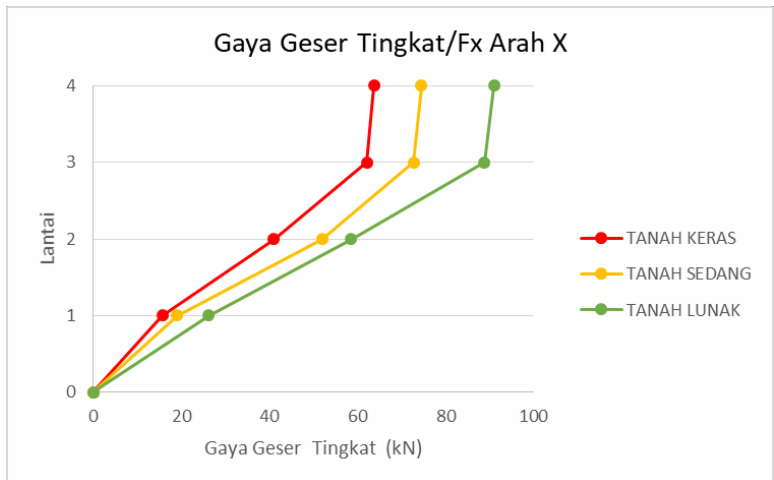

Gambar 4.11 Grafik gaya geser tingkat arah x

2. Gaya geser tingkat arah y

Gaya geser tingkat pada arah y yang paling besar terjadi pada tingkat 4 pada masing-masing kondisi tanah yang berbeda. Sedangkan untuk struktur yang mengalami gaya geser tingkat yang paling besar terjadi pada jenis tanah lunak. Hal ini dapat dilihat dalam tabel dan diagram dibawah ini.

Tabel 4.11 Gaya geser tingkat arah y

\begin{tabular}{|c|c|c|c|c|c|c|}
\hline \multirow{2}{*}{$\begin{array}{l}\text { La } \\
\text { nta } \\
\text { i }\end{array}$} & \multicolumn{3}{|c|}{$\begin{array}{l}\text { Gaya Geser tiap } \\
\text { lantai Arah Y }\end{array}$} & \multicolumn{3}{|c|}{$\begin{array}{l}\text { Gaya Geser } \\
\text { Tingkat (Fx) }\end{array}$} \\
\hline & $\begin{array}{l}\text { Tana } \\
\text { h } \\
\text { Keras } \\
\text { /C }\end{array}$ & \begin{tabular}{l}
\multicolumn{1}{c}{ Tana } \\
h \\
Sedan \\
g/D
\end{tabular} & $\begin{array}{l}\text { Tana } \\
\text { h } \\
\text { Lunak } \\
\text { /E }\end{array}$ & $\begin{array}{l}\text { Tana } \\
\mathbf{h} \\
\text { Keras } \\
\text { /C }\end{array}$ & \begin{tabular}{l}
\multicolumn{1}{c}{ Tan } \\
ah \\
Seda \\
ng/D
\end{tabular} & $\begin{array}{l}\text { Tan } \\
\text { ah } \\
\text { Luna } \\
k / E\end{array}$ \\
\hline 4 & $\begin{array}{l}62.3 \\
7\end{array}$ & $\begin{array}{l}71.7 \\
8\end{array}$ & $\begin{array}{l}91.6 \\
1\end{array}$ & $\begin{array}{l}62.3 \\
7\end{array}$ & $\begin{array}{l}71 . \\
78\end{array}$ & 91.61 \\
\hline 3 & $\begin{array}{l}121 . \\
07\end{array}$ & $\begin{array}{l}141 . \\
52\end{array}$ & $\begin{array}{l}180 . \\
59\end{array}$ & 58.7 & $\begin{array}{l}69 . \\
74 \\
\end{array}$ & 88.98 \\
\hline 2 & 160 & $\begin{array}{l}187 . \\
19\end{array}$ & $\begin{array}{l}238 . \\
82\end{array}$ & $\begin{array}{l}38.9 \\
3\end{array}$ & $\begin{array}{l}45 . \\
67\end{array}$ & 58.23 \\
\hline 1 & $\begin{array}{l}178 . \\
61\end{array}$ & $\begin{array}{l}208 . \\
87\end{array}$ & $\begin{array}{l}266 . \\
54\end{array}$ & $\begin{array}{l}18.6 \\
1\end{array}$ & $\begin{array}{l}21 . \\
68\end{array}$ & 27.72 \\
\hline
\end{tabular}




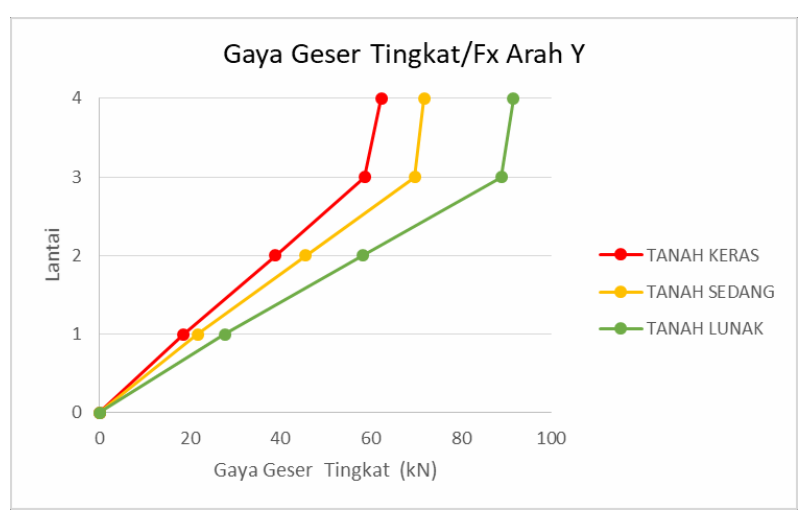

Gambar 4.12 Grafik gaya geser tingkat arah y

\section{PENUTUP}

Dari hasil pembahasan diatas dapat diuraikan kesimpulan dari hasil analisis yang telah dilakukan, bahwa perilaku struktur komposit pada gedung yang dimodelkan dengan program SAP2000 akibat beban gempa arah $x$ yaitu maupun y mengalami simpangan antar tingkat yang tidak melebihi dari simpangan lantai ijin sebesar $80 \mathrm{~mm}$ pada lantai 1 dan 72 $\mathrm{mm}$ pada lantai 2, 3 serta 4 dari ketiga kondisi tanah yang berbeda.

Dari ketiga jenis tanah yaitu tanah keras, tanah sedang dan tanah lunak yang digunakan untuk analisis pada struktur komposit ini, struktur mengalami simpangan maksimum sebesar $79,57 \mathrm{~mm}, 93,06 \mathrm{~mm}, 113,65 \mathrm{~mm}$, simpangan antar tingkat sebesar $23,05 \mathrm{~mm}, 26,96 \mathrm{~mm}$, $32,93 \mathrm{~mm}$, gaya geser dasar sebesar $182,58 \mathrm{kN}, 218,26 \mathrm{kN}, 264,56 \mathrm{kN}$, serta gaya geser tingkat sebesar $63,7 \mathrm{kN}, 74,48 \mathrm{kN}, 91$ $\mathrm{kN}$. Dari ketiga jenis tanah tersebut struktur mengalami simpangan maksimum, simpangan antar tingkat, gaya geser dasar dan gaya geser tingkat dengan nilai paling besar terjadi pada kondisi tanah lunak kemudian tanah sedang dan yang paling kecil di tanah keras.

\section{DAFTAR PUSTAKA}

Badan Standar Nasional. 2013. Beban Minimum untuk Perancangan Bangunan Gedung dan Struktur Lain. Jakarta : BSN.

Badan Standar Nasional . 2013. Persyaratan
Beton Struktural Untuk Bangunan Gedung. Jakarta : BSN.

Badan Standar Nasional. 2012. Tata Cara Perencanaan Ketahanan Gempa untuk Struktur Bangunan Gedung dan Non Gedung. Jakarta : BSN.

Departemen Pekerjaan Umum.1983. Pedoman Perencanaan Pembebanan untuk Rumah dan Gedung. Bandung : Yayasan Badan Penerbit PU.

Hastomi. 2013. Desain Struktur Beton Dengan SRPMK.

https://hastomiaf.wordpress.com/2013/09/ 28/desain-struktur-beton-dengan-srpmk22/. (Diakses tanggal tanggal 25 mei 2017).

Kementerian Pekerjaan Umum. 2010. Peta Hazard Gempa Indonesia. Jakarta: Kementerian PU.

Nawy, E.G. 2010. Beton Bertulang Suatu Pendekatan Dasar. Universitas Katolik Parahyangan : PT Reflika Aditama.

Prihatmoko, Amdhani. 2013. Perencanaan Struktur Gedung Beton Bertulang Dengan Sistem Rangka Pemikul Momen Khusus (SRPMK) Dan Sistem Rangka Pemikul Momen Menengah (SRPMM). Yogyakarta.

Soelarso, dkk. 2015. Analisis Struktur Beton Bertulang SRPMK Terhadap Beban Gempa Statik Dan Dinamik.

Peraturan SNI 1726 2012. Banten Widnyana, dkk. 2018. Pengaruh Interaksi TanahStruktur Terhadap Perilaku dan Kinerja Struktur Rangka Beton Bertulang di Atas Tanah dengan Kelas Situs SC, SD, dan SE. Bali.

Wiryadi, Gegiranang. 2018. Modul Pelatihan Dasar Program SAP2000. Denpasar : Fakultas Teknik Universitas Mahasaraswati Denpasar. 